\title{
Analisis Persepsi Konsumen Terkait Rebranding Logo Carvil
}

\author{
Sampras Nugroho, Widayatmoko, Muhammad Adi Pribadi \\ Sampras.915150033@stu.untar.ac.id,widayatmoko@fikom.untar.ac.id,adiposts@gmail.com
}

Fakultas Ilmu Komunikasi Universitas Tarumanagara

\begin{abstract}
Carvil is a sandals brand that has been established since 1978. People known carvil for the price and quality of their products, all are worthy of praise by the community. Along with the changing times and fashion changes that are increasing. Carvil rebranding the logo to keep up with the times and fashion. The formulation of the problem in this study is how the public perception is related to the rebranding of the Carvil logo. The purpose of this study was to determine consumer perceptions regarding the rebranding of the Carvil logo. The main theories used in this study are consumer perception, and rebranding. The type of research used is qualitative research with a case study research strategy. The outcome of this study came from various consumers' perception while carvil's rebranding of the Carvil logo is that Carvil does not seem old-fashioned and wants to follow the trend, and can compete with its competitors. The results of this study the author draws the conclusion that the perceptions received by consumers are in accordance with what Carvil wants, where consumers perceive that Carvil changes the logo by reason of wanting to be seen as a trend and want to keep up with the times.
\end{abstract}

Keyword : rebranding, consumers perceptions

\begin{abstract}
Abstrak
Carvil adalah merek sendal yang sudah ada sejak tahun1978. Masyarakat telah mengenal baik tentang carvil dari harga dan kualitas semua dipuji oleh masyarakat. Dengan perkembangan jaman dan perubahan fashion yang meningkat. Carvil melakukan rebranding logo untuk bisa mengikuti perkembangan jaman dan fashion. Permasalah dalam penelitian ini yaitu bagaimana persepsi masyarakat terkait rebranding logo Carvil. Penulis melakuka penelitian ini untuk mengetahui persepsi konsumen terkait rebranding logo Carvil. Jenis teori yang digunakan dalam penelitian ini adalah teori persepsi konsumen, dan rebranding. Jenis penelitian yang digunakan dalam khasanah ruang kualitatif dengan metode studi kasus. Temuan dari penelitian ini adalah persepsi konsumen terhadap rebranding logo Carvil adalah Carvil tidak terkesan kuno dan ingin mengikuti trend yang ada, dan dapat bersaing dengan pesaingnya. Hasil dari penelitian ini penulis menarik kesimpulan bahwa persepsi yang diterima oleh konsumen sesuai dengan yang diinginkan Carvil dimana para konsumen mempersepsikan bahwa Carvil melakukan perubahan logo dengan alasan ingin terlihat trend dan ingin mengikuti perkembangan jaman.
\end{abstract}

\section{Kata kunci : rebranding, persepsi konsumen}

\section{Pendahuluan}

Kebutuhan penting manusia terbagi atas kebutuhan pakaian (sandang), makanan (pangan), dan kebutuhan keamanan (papan). Fungsi kebutuhan sandang menjadi sorotan dari penelitian yang dilakukan dan menjadi dasar dari penggunaan teori. Kebutuhan akan sandang itu sendiri terbagi atas baju, celana, sepatu dan lain sebagainya. 
Sejarah sepatu sendiri berasal dari cerita masyarakat di mesir pada abad ke-15 SM, dimana Bangsa Mesir digambarkan sebagai bangsa yang sibuk bekerja untuk memproduksi sandal, sedangkan seorang lagi terlihat sedang menjahit sepatu dari gambar lukisan Mesir Kuno di Thebes, Mesir. Pada zaman itu, alas kaki dan sepatu terbuat menggunakan bahan - bahan pilihan yang terus berkembang berdasarkan zaman dari kreativitas desainer atau pencipta desain, contoh dari bahan-bahan yang digunakan adalah kain, daun palem, papirus, kulit atau bahan yang sejinis dan membuat anyaman. (https://www.finansialku.com/carvil-waralaba-sukses/)

Berdasarkan kehidupan sosial di masyarakat, fungsi sepatu sudah beralih fungsi dari kebutuhan primer menjadi kebutuhan sekunder seperti busana (fashion) yang dikategorikan ke dalam kebutuhan sekunder di barang mewah. Bahan yang digunakan dan modelnya pun semakin bervariasi. Meski begitu, dalam penggunaan dan fungsinya, sepatu akan selalu dibutuhkan sebagai kebutuhan primer masyarakat sosial, dan untuk weaktu yang lama di kehidupan masyarakat sosial alas kaki akan terus menjadi produk komoditi yang akan dipenuhi dalam kegiatan industri produsen.

Logo merupakan lambang dan identitas bagi sebuah perusahaan. Logo sendiri berfungsi sebagai pengingat bagi konsumen agar mudah diingat dan dikenal oleh para konsumennya. Persepsi konsumen harus disikapi dengan baik oleh perusahaan, salah satunya adalah dengan menciptakan citra perusahaan yang baik dimata konsumen.

Menurut Pujiyanto (2013) dalam (Sriwitari : 2014,97)dalam bukunya yang berjudul Desain Komunikasi Visual, mengungkapkan bahwa logo adalah peyingkatan dari logotype.

Begitu banyak merek - merek atau brand sepatu dan sendal di Indonesia, dari banyaknya merek - merek atau brand tersebut ada beberapa dari merek yang melakukan rebranding terhadap logonya. Rebranding terhadap logo dilakukan agar mereka dapat menyesuaikan dengan perkembangan zaman serta ada perubahan visi dan misi terhadap brand tersebut.

Carvil sendiri sudah berdiri sejak tahun 1978 hingga sekarang, dia adalah salah satu brand lokal yang masih bertahan diperkembangan jaman. Carvil sendiri melakukan perubahan logo diawal tahun 2018, pada awal tahun itu Carvil memperkenalkan logo barunya dimata masyarakat.

Menurut latar bekang masalah yang diteliti penulis, maka penulis melihat pentingnya pesepsi konsumen terhadap rebranding logo, maka dari tiu penulis tertarik untuk mengadakan penelitian dengan judul: "ANALISIS PERSEPSI KONSUMEN TERKAIT REBRANDING LOGO CARVIL".

Berdasarkan rangkaian latar belakang masalah yang telah dipaparkan sebelumnya, maka dapat ditarik sebuah rumusan masalah bagaimana persepsi masyarakat terkait rebranding logo Carvil ? Adapun tujuan penelitian ini adalah untuk mengetahui persepsi konsumen terkait dengan rebranding logo Carvil.

Menurut Suryani (2012:97), persepsi adalah suatu proses di mana seseorang dapat memilih, mengelompokkan, dan menginteprestasikan stimuli menjadi suatu yang berarti. Menurut Muzelle et.al $(2003,32)$ rebranding terdiri dari dua kata yakni " $r e$ " memberikan arti melakukan hal untuk kedua kalinya atau pengulangan dan "Brand" berdasarkan hal tersebut dapat dikatakan bahwa rebranding sebagai praktek membangun sebuah nama baru kembali yang mewakili posisi yang berbeda dalam benak pemegang kepentingan (stakholders) dan sebuah identitas khusus dibanding dengan kompetitor. 
Sampras Nugroho, Widayatmoko, Muhammad Adi Pribadi: Analisis Persepsi Konsumen Terkait Rebranding Logo Carvil

\section{Metode Penelitian}

Melalui penelitian ini, penulis akan menggunakan jenis pendekatan dalam khasanah kualitatif. Menurut Moleong (2011:6) mengatakan bahwa penelitian kualitatif adalah peneletian yang bermaksud untuk memahami fenomena tentang apa yang dialami oleh subjek penelitian misalnya perilaku, persepsi, motivasi, tindakan dan lain - lain secara holistic, dan dengan cara deskripsi dalam bentuk kata - kata dan bahasa, pada suatu konteks khusus yang alamiah dan dengan memanfaatkan berbagai metode alamiah.

Alasan penulis menggunakan pendeketan penelitian kualitatif karena dari topik yang diangkat oleh penulis yang berjudul "Analisis Persepsi Konsumen Terkait Rebranding Logo Carvil".

Metode penelitian yang penulis lakukan untuk meraih data dan kesimpulan dari rumusan masalah penelitian ini adalah studi kasus. Menurut Yin (2013:1) studi kasus merupakan satu metode penelitian tentang ilmu sosial dimana jenis pertanyaa mengapa dan bagaimana lebih cocok dalam meraih data dari kasus yang ada.

Subjek dalam konsep penelitian merujuk pada responden, informan yang hendak diminta informasi atau digali datanya. Subjek penelitian ini adalah masyarakat pengguna carvil, ahli branding, dan pihak Carvil. Objek penelitian merupakan adalah topik permasalahan yang diangkat dalam tema yang diteliti. Objek penelitian merupakan apa yang jadi sasaran penelitian. Maka itu objek dari penelitian yang penulis teliti adalah persepsi masyarakat dan rebranding logo.

Metode pengumpulan data adalah teknik untuk mengumpulkan data yang dilakukan untuk meraih kebutuhan selama penelitian. Studi kasus memiliki 6 sumber bukti yang tidak sama diantaranya : dokumentasi, rekaman data, wawancara, pengamatan secara langsung, observasi secara langsung, dan perangkat fisik. Dalam penelitian ini, peneliti menggunakan metode observasi terhadap objek, wawancara bersama narasumber kunci, dan kajian pustaka dalam buku.

Menurut (Moleong 2004:330) triangulasi adalah teknik pemeriksaan keabsahan data yang memanfaatkan sesuatu yang lain dalam membandingkan hasil wawancara terhadap objek penelitian.

Adapun yang dimaksud triangulasi yaitu mencocokkan dari hasil yang menggunakan berbagai sumber informasi dan berbagai metode pengumpulan data, sedangkan triangulasi yang digunakan dalam penelitian ini adalah Triangulasi sumber data maksudnya membandingkan balik derajat dari kepercayaan informasi yang diperoleh ketika waktu penelitian bertempat serta nstrumen yang berbeda dalam metode pendekatan kualitatif, seperti yang dikatakan oleh (Lexy, 2007:178) hal itu dapat dilakukan dengan cara:

A. Melakukan perbandingan data hasil observasi dengan hasil wawancara.

B. Melakukan perbandingan dengan apa yang dibicarakan dengan orang dimuka umum dengan apa yang dikatakannya secara sendiri.

C. Melakukan perbandingan dengan apa yang dibicarakan orang mengenai tindakan penelitian dengan apa yang sepanjang waktu.

D. Melakukan perbandingan keadaan dan pandangan orang dari berbagai pendapat dan pandangan orang lain, melakukan perbandingan ini akan dijelaskan perselisihan atas latar belakang alasan - alasan terjadinya bandingan pendapat maupun pandangan orang.

E. Melakukan pembandingan dari hasil yang didapat dari wawancara bersama narasumber dan observasi dari dokumen. 


\section{Hasil temuan dan analisis}

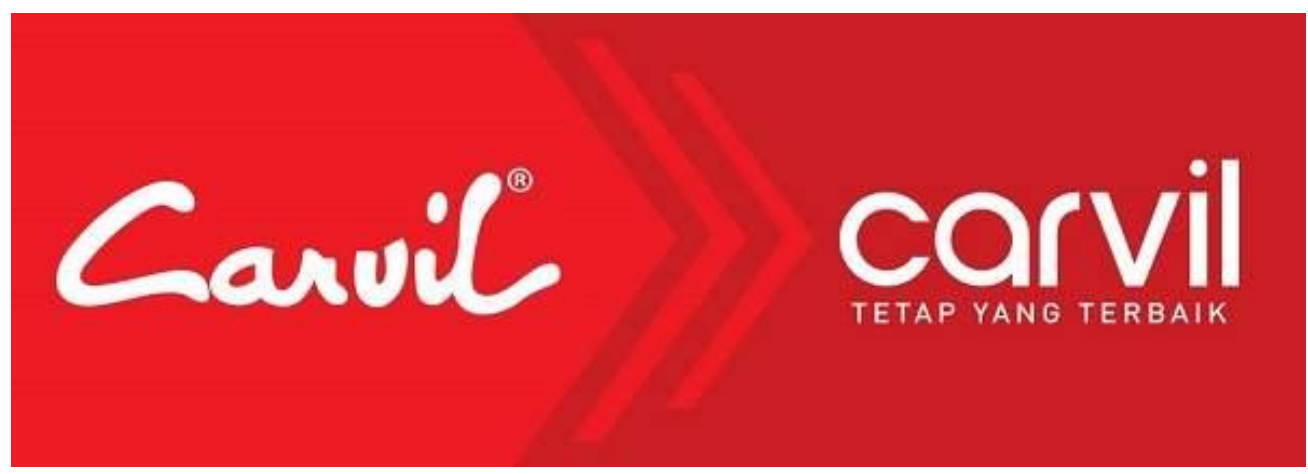

Setelah melakukan observasi dan melakukan wawancara dengan para narasumber. Pada kesempatan ini penulis mempaparkan hasil temuan dari suatu penitian mengenai analisis persepsi konsumen terkait rebranding logo Carvil.

Dari hasil wawancara yang dilakukan penulis kepada para narasumber logo sebuh perusahaan sendiri memiliki arti mengenai pesan apa yang ingin disampaikan dari perusahaan kepada para konsumennya. Bila sebuah perusahaan melakukan perubahan logo harus segera disampaikan kepada para konsumennya. Bila perusahaan melakukan perubahan logo dan tidak disampaikan lagi kepada konsumennya. Para konsumen bisa meragukan keaslian dari produk tersebut.

Sebelum melakukan perubahan logo sebuah perusahaan harus mengetahui menyebab atau masalah yang dihadapi dari perusahaan tersebut, agar tidak salah mengambil tindakan. Banyak perusahaan yang melakukan perubahan logo dikarenakan mengikuti pesaingnya, sebenarnya itu ada kesalahan.

Sebuah perusahaan ingin melakukan perubahan harus mengetahui masalah yang dihadapinya, lakukanlah analisis, dan tentukan strategi untuk menghadapinya dan yang terakhir laksanakan, agar masalah yang dihadapi cepat selesai.

Carvil melakukan perubahan logo terbukti memiliki 2 faktor yaitu faktor yang berasal dari dalam dan luar perusaahaan:

Faktor internal yang menjadi salah satu alasan mengapa carvil melakukan rebranding adalah target pasar Carvil ingin meluas agar dapat mencangkup kaum milenial, Carvil sendiri agak sulit menggapai kaum milenial dikarenakan kaum milenial memiliki selera model yang berbeda dengan target pasar yang sebelumnya.

Faktor Eksternalnya adalah perubahan jaman dari tahun ke tahun, perkembangan fashion atau model yang semakin meningkat. Carvil sendiri harus bisa mengikuti perkembangannya bila ingin bertahan.

Setelah mengetahui dan melaksanakan strategi, sebuah perusahaan harus melakukan perkenalan kembali logo baru yang dilakukan agar masyarakat mengetahui perubahan yang dilakukan oleh perusahaan. Perkenalakan kembali dapat dilakukan dengan berbagai cara dari diperkenalakan melalui media online atau offline.

Carvil melakukan perubahan logo, Carvil harus bisa melakukan brand repositioning dikarenakan setelah melakukan perubahan logo sebuah sebuah perusahaan harus bisa mendapatkan persepsi atau pandangan baru dimata masyarakat dan konsumennya.

Dari hasil Carvil mempersepsikan konsumen yang terkait dalam faktor internal adalah bagian fisiologis, dan perhatian. Faktor lain yang mempengaruhi keputusan Carvil adalah faktor diluar dari perusahaan, yaitu pengaruh dari konsumen Carvil yaitu 
ukuran dan penempatan dari objek stimulus, warna dan objek, intensitas dan kekuatan dari stimulus.

Dilihat dari faktor fisiologis dapat mempengaruhi konsumen dikarenakan para narasumber mendapatkan informasi melalui alat indera yang diterimanya. Dari faktor perhatian, para konsumen memberikan pendapat mereka tentang perhatian yang mereka berikan kepada logo Carvil yang baru.

Faktor dari ukuran dan penempatan dari objek stimulus mempengaruhi konsumen dari luar dikarenakan mereka melihat logo Carvil sekarang memiliki tulisan yang lebih besar, faktor warna dan objek mempengaruhi persepsi seseorang dikarenakan sudah dengan ciri khas warna yang biasa di gunakan oleh logo carvil sendiri, faktor intensitas dan kekuatan dari stimulus mempengaruhi dikarenakan para konsumen melihat iklan logo Carvil yang baru melalui televisi, media sosial dan media offline lainnya seperti spanduk dll.

Carvil merubah logonya dikarenan untuk mengikuiti perkembangan jaman dan perkembangan fashion yang semakin meningkat. Carvil sendiri ingin merubah persepsi para konsumen yang lama dikarenakan ada konsumen menganggap bahwa Carvil terlihat kuno, dengan melakukan rebranding ingin terlihat lebih trend.

\section{Kesimpulan}

Pemaparan dan hasil yang dapat dikemukakan pada penelitisn ini dilakukan dengan pendekatan kualitatif, maka dapat disimpulkan bahwa persepsi masyarakat terkait rebranding logo Carvil sesuai dengan yang diharapkan brand Carvil. Terdapat dibenak konsumen tentang rebranding logo Carvil supaya tidak terkesan masih kuno dan ingin mengikuti trend yang ada. Carvil sendiri ingin konsumen mempersepsikan mereknya, bahwa merek Carvil tersebut lebih trend dan bisa mengikuti jaman. Carvil berhasil membuat persepsi masyarakat dalam bentuk media cetak dan elektronik, dengan demikian konsumen-konsumen Carvil bisa mempersepsikannya. Berdasarkan hasil tersbut bahwa pesan yang ingin sampai kan dengan melakukan rebranding tersampaikan dengan baik.

\section{Ucapan terima kasih}

Penulis mengucapkan terima kasih kepada Bapak Drs. Widayatmoko, M.M., M.I.Kom, dan Bapak Dr. Muhammad Adi Pribadi, S.E., M.I.B.,M.Com., selaku pembimbing dan co - pembimbing yang selalu memberikan arahan, bantuan dan meluangkan waktunya membimbing penulis. Para narasumber dan konsumenkonsumen yang memberikan informasi yang dibutuhkan oleh penulis supada dapat menyelesaikan tugas akhir skripsi. Tak lupa mengucapkan kepada kedua orang tua, saudara, dan teman-teman yang selalu memberika dukungan dan bantuan kepada penulis.

\section{Daftar pustaka}

Suryani, Tatik 2012. Perilaku konsumen: Implikasi pada Strategi Pemasaran. Edisi Pertama. Penerbit: Graha Ilmu.

Sriwitari, Widnyana.2014. Desain Komunikasi Visual. Yogyakarta:GRAHA ILMU. Muzellec, Laurent, Manus Doogan, and Mary Lambkin. 2003. Corporate RebrandingAn Exploratory Review Irish Marketing Review. 16 
Moleong, Lezy J. 2011. Metode Penelitian Kualitatif. Bandung : PT Remaja Rosdakarya. hal : 6.

Yin, Robert K. 2013 . Studi Kasus Desain dan Metode. Jakarta: PT. Raja Grafindo Persada.

Moloeng, lexy J. 2004. Metode Penelitian Kualitatif. Bandung : Rosda

Lexy J. Moelong. 2007. Metodologi Penelitian Kualitatif, Bandung: Remaja Rosdakarya, 